\title{
LESSON STUDY SEBAGAI UPAYA UNTUK MENINGKATKAN KEMAMPUAN PEMAHAMAN DAN IDENTIFIKASI MAHASISWA DALAM MATA KULIAH PERSAMAAN DIFERENSIAL
}

\author{
Rubono Setiawan \\ Program Studi Pendidikan Matematika,FKIP Universitas Sebelas Maret
}

\begin{abstract}
Abstrak: Tujuan dari penelitian ini adalah untuk mengetahui pengaruh menerapkan Lesson Study dalam perkuliahan persamaan diferensial terhadap tingkat pemahaman mahasiswa yang tercermin dari prestasi hasil belajarnya. penyelesaian persamaan diferensial. Data yang dikumpulkan adalah data uraian tentang tingkat keaktifan mahasiswa dalam perkuliahan, mengerjakan lembar kerja individu dan kelompok serta mengerjakan tugas pekerjaan rumah, data tersebut didukung dari data dosen observer. Teknik analisis data dengan deskriptif kualitatif, karena sebagian besar data berupa uraian deskriptif. Lesson Study dilaksanakan dengan 4 siklus dalam 4 kompetensi dasar. Berdasarkan analisis dalam 4 siklus menunjukkan peningkatan dalam hal keaktifan dan proses pembelajaran dan mengerjakan lembar kerja pribadi, kelompok dan tugas rumah. Hal tersebut juga sejalan dengan hasil capaian prestasi mahasiswa yang semakin meningkat satu siklus ke siklus lainnya dan telah melebihi target capaian prestasi yang diinginkan. Dalam Lesson Study ini lebih ditekankan pada praktek mengerjakan soal soal Persamaan Diferensial.
\end{abstract}

Kata kunci: Lesson Study, Persamaan Diferensial, Plan, Do, See

\begin{abstract}
The purpose of this study is to determine the effect of applying Lesson Study in the lecture of differential equations to the level of understanding of students as reflected by the achievement of learning outcomes.The main data collected in many form such us of rate of activity of undergraduate student in the class, worksheet in individual and also in group and then result of their homework. Data is also collected from observation result from several observers in the class. Descriptive qualitative research has been used to analyze the process of lesson study. This lesson study is enforced in four cycle of basic of competency. Based on analysis in each cycle, it shows an increase in terms of learning process and working process on personal worksheets, groups and homework exercises. In Lesson Study it is more emphasized on the practice of working on problems about Differential Equations.
\end{abstract}

Keywords: Lesson Study, Differential Equations, Plan, Do, See 


\section{PENDAHULUAN}

Persamaan diferensial merupakan salah satu mata kuliah wajib yang harus ditempuh oleh mahasiswa pendidikan matematika Universitas Sebelas Maret. Sifat mata kuliah ini yang membuatnya menjadi mata kuliah yang dirasa cukup sulit oleh mahasiswa. Konsep - konsep kalkulus tentang kalkulus dan integral mutlak telah dikuasai oleh mahasiswa ketika mengikuti perkuliahan ini. Isi dari perkuliahan tersebut sendiri yang memuat banyak metode dalam menentukan penyelesaian jenis jenis persamaan diferensial, dimana setiap jenis persamaan diferensial mempunyai metode tersendiri untuk dapat diselesaikan. Selain itu, oleh karena struktur dan konsep persamaan diferensial merupakan suatu hal yang baru bagi mahasiswa yang baru mengambil, sehingga membutuhkan penjelasan mengenai konsep dan serta movitasi yang lebih banyak. Menurut pengalaman penulis, hal hal tersebut yang membuat mata kuliah ini sering dianggap sulit untuk dipahami bagi sebagian besar mahasiswa, terutama adalah ketika menyelesaiakan suatu persamaan diferensial dimana metode yang digunakan memperlukan langkah yang cukup banyak. Menurut pengalaman penulis permasalahan yang sering dialami oleh mahasiswa dalam perkuliahan persamaan diferensial adalah Identifikasi : identifikasi yang dimaksud disini adalah identifikasi jenis - jenis persamaan diferensial, baik yang masuk kelompok persamaan diferensial tingkat 1 , tingkat 2 ataupun lebih maupun kelompok sistem persamaan diferensial dan kemudian ditentukan metode apa yang cocok untuk menyelesaikan masing masing jenis persamaan diferensial tersebut. Hal ini menjadi cukup sulit karena setiap jenis persamaan diferensial mempunyai cara penyelesaian yang berbeda beda, sehingga mahasiswa harus bisa mengidentifikasi persamaan diferensial tersebut agar metode yang digunakan tepat, karena penggunaan metode yang tidak tepat akan berakibat suatu persamaan diferensial tidak akan dapat ditemukan penyelesaiannya.

Pemahaman Konsep : pemahaman disini adalah pemahaman konsep di dalam setiap langkah penyelesaian suatu persamaan diferensial. Banyak metode yang membutuhkan pemahaman konsep yang kuat dalam setiap langkahnya, agar metode tersebut bisa diterjemahkan dan diaplikasikan dengan tepat. Sebagai contoh metode koefisien tak tentu dan 
metode variasi parameter dalam menyelesaikan persamaan diferensial tak linear tingkat 2. Selain permasalahan tersebut permasalahan lain yang mengikuti adalah motivasi mahasiswa dalam belajar persamaan diferensial. Karena tingkat kerumitan dan kesulitan mata kuliah ini, maka motivasi dalam mempelajarinya seringkali berkurang bagi sebagian besar mahasiswa, sehingga hal ini tentu dapat mengurangi hasil belajar.

Berdasarkan alasan bahwa persamaan diferensial merupakan mata kuliah yang mayoritas standar komptensinya adalah dari segi praktis dalam penyelesaian soal soal persamaan diferensial, maka fokus utama permasalahan yang ingin dibahas adalah model pembelajaran yang seperti apa yang tepat untuk meningkatkan pemahaman mahasiswa dalam identifikasi jenis jenis persamaan diferensial serta penguatan pemahaman dalam penggunaan metode dalam penyelesaian persamaan diferensial, sehingga diharapkan hasil belajar mahasiswa dalam hal ini nilai tiap kompetensi dasar akan menjadi baik.

Proses pembelajaran yang menjadi obyek penelitian adalah perkuliahan persamaan diferensial pada kelas SBI ( C ) semester genap tahun ajaran 2013/2014 di Prodi Pendidikan Matematika Fakultas Keguruan dan Ilmu Pendidikan Universitas Sebelas Maret Surakarta dimana penulis bertindak sebagai pengampu mata kuliah ini. Dalam perkuliahan ini direncanakan akan dicari model pembelajaran yang tepat untuk meningkatkan pemahaman mahasiswa dalam permasalahan persamaan diferensial yang utamanya adalah (a) Bagaimana meningkatkan pemahaman mahasiswa dalam hal identifikasi jenis jenis persamaan diferensial, terutama persamaan diferensial yang tingkat dan strukturnya sulit ?;(b)Bagaiamana meningkatkan pemahaman mahasiswa mengenai langkah langkah penyelesaian dari setiap metode penyelesaian jenis jenis persamaan diferensial ?

$$
\text { Menurut Sujadi (2011),lesson }
$$
study memberi peluang untuk perbaikan kualitas pembelajaran. Lesson study telah dilaksanakan di Indonesia sejak tahun 2006 dan dalam perkembangannya, lesson study di Indonesia didefinisikan sebagai suatu model pembinaan profesi pendidik melalui pengkajian pembelajaran secara kolaboratif dan berkelanjutan berdasarkan prinsip-prinsip kolegialitas dan mutual learning untuk membangun learning community (Herawaty dkk., 2010). 
Dalam upaya untuk mencari penyelesaian dari permasalah di atas maka dipilihlah model Lesson Study dengan menggunakan kombinasi metode ceramah dan penekanan pada metode diskusi kelompok . Lesson Study dilaksanakan mulai dari kompetensi dasar 1 sampai kompetensi dasar 4. Metode ceramah tetap digunakan karena konsep konsep dan metode metode dalam persamaan diferensial memang tergolong baru dan rumit bagi mahasiswa, sehingga harus dijelaskan terlebih dahulu. Metode diskusi kelompok digunakan sebagai sarana untuk penguatan materi materi tertentu dalam setiap kompetensi dasar. Pemilihan materi tersebut dipilih dengan pertimbangan kesulitan struktur dan juga kerumitan metode penyelesainnya. Diskusi kelompok ditekankan pada penyelesaian masalah persamaan diferensial. Alasan lain adalah dengan adanya Lesson Study ini diharapkan juga sebagai sarana bagi pengajar sendiri untuk meningkatkan kemampuan menjelaskan serta saling bertukar pikiran serta saran karena melibatkan dosen bidang materi yang juga mengampu persamaan diferensial serta analisis sebagai observer dalam proses Lesson Study (lewis, 2002). Akhirnya, tujuan dari penelitian ini adalah untuk mengetahui pengaruh menerapkan Lesson Study dalam perkuliahan persamaan diferensial terhadap tingkat pemahaman mahasiswa yang tercermin dari prestasi hasil belajarnya.

\section{METODE PENELITIAN}

\section{Subjek Penelitian}

Subjek penelitian Lesson Study ini adalah mahasiswa Prodi Pendidikan Matematika FKIP UNS peserta mata kuliah persamaan diferensial kelas SBI pada semester genap 2012/2013.

\section{Rancangan Pelaksanaan}

Lesson Study dilaksanakan dalam 4 siklus dalam 4 kompetensi kompetensi dasar (KD). Kompetensi Dasar 1 (KD 1) yang sepenuhnya menggunakan metode pembelajaran ceramah, Plan sebelum perkuliahan dimulai dan Do dilakukan pada 3 pertemuan pertama sebelum KD 1 , proses See dilakukan dengan mendiskusikan hasil pembelajaran. Untuk KD 2 sampai 4 proses Plan, Do dan See, pelaksanaannya dapat dilihat dalam tabel berikut : 
Tabel 1. Tahapan Proses Pelaksanaan

\begin{tabular}{|c|c|c|c|c|c|}
\hline No & $\begin{array}{l}\text { Sikl } \\
\text { us }\end{array}$ & $\begin{array}{c}\text { Tahap } \\
\text { Plan }\end{array}$ & \multicolumn{2}{|c|}{ Tahap Do } & $\begin{array}{c}\text { Tahap } \\
\text { See }\end{array}$ \\
\hline \multirow[t]{9}{*}{1} & $\mathrm{KD}$ & 11 April & 12 & April & Open \\
\hline & 2 & 2013 & 2013 & & Lesson \\
\hline & & Plan & 19 & April & Study : 26 \\
\hline & & Open & 2013 & & April 2013 \\
\hline & & Lesson: & 26 & April & diikuti \\
\hline & & 25 April & 2013 & (Open & Refleksi \\
\hline & & 2013 & Lesson & & setelah \\
\hline & & & Study) & & perkuliaha \\
\hline & & & & & $\mathrm{n}$ \\
\hline \multirow[t]{9}{*}{21} & $\mathrm{KD}$ & 16 Mei & 17 & Mei & Open \\
\hline & 3 & 2013 & 2013 & & Lesson \\
\hline & & Plan & 24 & Mei & Study : 31 \\
\hline & & Open & 2013 & & Mei \\
\hline & & Lesson: & 31 & Mei & diikuti \\
\hline & & 30 Mei & 2013 & ( & Refleksi \\
\hline & & 2013 & Open & & setelah \\
\hline & & & Lesson & & perkuliaha \\
\hline & & & Study) & & $\mathrm{n}$ \\
\hline \multirow[t]{10}{*}{3} & $\mathrm{KD}$ & 13 Juni & 14 & Juni & Open \\
\hline & 4 & 2013 & 2013 & & Lesson \\
\hline & & Plan & 21 & Juni & Study: \\
\hline & & Open & 2013 & & $28 \quad$ Juni \\
\hline & & Lesson: & 28 & Juni & 2013 \\
\hline & & 27 Juni & 2013 & ( & Diikuti \\
\hline & & 2013 & Open & & Refleksi \\
\hline & & & Lesson & & setelah \\
\hline & & & Study) & & perkuliaha \\
\hline & & & & & $\mathrm{n}$ \\
\hline
\end{tabular}

Rincian dosen model dan dosen obsever adalah sebagai berikut :
Tabel 2. Rincian Dosen Model dan Observer

\begin{tabular}{|c|c|c|}
\hline No. & NAMA & PERAN \\
\hline \multirow[t]{2}{*}{1.} & Drs. Soeyono, M.Si. & Dosen \\
\hline & & Pengamat \\
\hline \multirow[t]{2}{*}{2.} & Drs. Mardjuki, M.Si. & Dosen \\
\hline & & Pengamat \\
\hline \multirow[t]{2}{*}{3.} & Dyah Ratri Aryuna, & Dosen \\
\hline & S.Pd.,M.Si. & Pengamat \\
\hline 4. & $\begin{array}{l}\text { Rubono Setiawan, } \\
\text { S.Si.,M.Sc. }\end{array}$ & Dosen Model \\
\hline
\end{tabular}

\section{Data dan Pengumpulan Data}

Data yang dikumpulkan meliputi keseluruhan kegiatan pelaksanaan dari awal sampai akhir mengenai : 1. Proses penyusunan bahan ajar dan format lembar kerja individu dan kelompok serta tugas mandiri sebagai pekerjaan rumah, 2. Data tentang tingkat keaktifan mahasiswa dalam pembelajaran sebagai individu maupun kelompok, 3.Data tentang tingkat kemauan mahasiswa mengerjakan lembar kerja individu maupun lembar kerja dalam kelompok yang telah dirancang oleh dosen. 3. Data tentang tingkat kemauan mahasiswa mengerjakan tugas tugas pekerjaan rumah yang telah dirancang oleh dosen sesuai dengan karakteristik tiap siklus (tiap KD). 4. Data yang berasal dari pengamatan dosen observer saat pelaksanaan open lesson study sebagai pendukung. Data data tersebut dikumpulkan pada tiap siklus atau kompetensi dasar. 


\section{Teknik Analisis Data}

Teknik analisis data yang dilakukan adalah deskriptif kualitatif, karena sebagian besar data yang dikumpulkan adalah berupa uraian deskriptif tentang kemauan dan keaktifan mahasiswa dalam pembelajaran, mengerjakan lembar kerja individu maupun berkelompok dan juga mengerjakan tugas tugas yang dirancang dosen sesuai dengan karakteristik tiap siklus (tiap KD), serta uraian deskriptif dari dosen dosen observer saat proses open lesson study (Widhiartha.2008)

\section{PEMBAHASAN}

Perangkat pembelajaran utama dalam mata kuliah ini adalah Silabus, Rencana Pelaksanaan Pembelajaran, Bahan Ajar, Slide Power Point, Lembar Kerja individu dan kelompok serta format tugas sebagai pekerjaan rumah. Lembar Observasi adalah instrumen yang diisi oleh dosen observer dan digunakan untuk melihat aktivitas mahasiswa di dalam kelas saat pelaksanaan Open Lesson Study. Kemudian lembar kerja individu dan kelompok serta tugas disusun berdasarkan materi yang sesuai berdasarkan kesulitan materi yang dirasa perlu untuk ditekankan tingkat pemahamannya. Bahan Ajar yang digunakan adalah bahan ajar persamaan diferensial untuk KKD 1, KKD 2, KKD 3 dan KKD 4. Materi pada Kompetensi Dasar (KD) I meliputi pengertian, unsur,jenis, penyelesaian,eksistensi penyelesaian dan masalah syarat awal persamaan diferensial, kemudian dilanjutkan dengan pengertian persamaan diferensial tingkat 1 beserta eksistensi penyelesaian dan masalah syarat awalnya sampai pada persamaan diferensial tingkat 1 jenis variable terpisah dan persamaan diferensial homogen. Kompetensi Dasar (KD) 2 meliputi persamaan diferensial linear, persamaan Bernoulli, persamaan diferensial eksak dan non eksak serta faktor integral.

Kompetensi Dasar (KD) 3 meliputi persamaan diferensial tingkat 2 atau lebih, persamaan diferensial linear dengan koefisien konstan, persamaan diferensial non linear, metode variasi parameter, metode koefisien tak tentu, persamaan Cauchy Euler sampai dengan solusi deret dari persamaan diferensial linear. Kompetensi Dasar (KD) 4 meliputi sistem persamaan diferensial linear, metode operator untuk menyelesaikan sistem persamaan diferensial linear bentuk umum, metode nilai eigen untuk sistem persamaan diferensial linear bentuk normal. 
Pelaksanaan Lesson Study Tiap Siklus

Pelaksanaan Lesson Study

dilaksanakan dalam 4 siklus dalam 4 kompetensi dasar (KD). Khusus untuk materi pada kompetensi dasar 1 sebagai siklus 1 , penyajian perkuliahan disajikan sepenuhnya dengan metode ceramah tentang materi dan motivasi belajar persamaan diferensial, hal ini dirasa sangat perlu agar mahasiswa mempunyai gambaran awal yang cukup tentang apa itu persamaan diferensial dan juga penggunaannya. Materi - materi yang akan disampaikan telah didiskusikan terlebih dahulu (Plan) dengan dosen dosen rumpun materi sebagai dosen observer. Untuk KD 2 sampai dengan KD 4, dilaksanakan 3 tahap Lesson Study pada tiap kompetensi dasar dengan 1 pertemuan sebagai Open Lesson Study pada tiap kompetensi dasar. Kegiatan Open Lesson Study dihadiri oleh dosen observer merupakan bagian dari tahapan See, dimana dosen observer ikut mengamati dalam kegiatan pembelajaran dan kemudian dilanjutkan kegiatan refleksi membahas perkuliahan yang telah dilaksanakan. Kegiatan Refleksi berisi saran-saran dari dosen observer dan juga saling member masukan antar dosen observer dan dosen model. Berikut uraian kegiatan secara lengkap pada tiap siklus :

\section{Siklus 1 (Kompetensi Dasar 1)}

Plan

Dalam tahap ini dosen pengampu mempersiapkan telah mempersiapkan Silabus dan Rencana Pelaksanaan Pembelajaran ( RPP) dan bahan ajar yang dibutuhkan selama 3 pertemuan pertama di KD 1, Silabus dan RPP telah didiskusikan dengan rumpun bidang studi dan telah diverifikasi oleh koordinator rumpun bidang studi matematika terapan. Kemudian Silabus dan RPP tersebut didiskusikan dengan dosen observer untuk mendapat saran perbaikan dan penyempurnaan. Selain itu juga disiapkan juga format format tugas yang nantinya akan diberikan kepada mahasiswa

\section{Do}

Tahap ini meliputi pembelajaran di dalam kelas yang terdiri atas 3 tatap muka dan diakhiri dengan ujian kompetensi dasar pada pertemuan keempat. Penyampaian materi hampir sepenuhnya dilakukan dengan metode ceramah. Metode ini dipilih dengan alasan karena materi persamaan diferensial masih tergolong baru bagi mahasiswa yang baru menempuh. Pemberian motivasi mengenai pentingnya belajar persamaan diferensial sangat ditekankan disini, diberikan penjelasan bahwa persamaan diferensial 
banyak digunakan dalam pemodelan matematika dalam kehidupan nyata lewat pemberian banyak contoh dan ilustrasi. Selain itu, pemberian materi pengertian persamaan diferensial dan metode penyelesaian persamaan diferensial yang paling mendasar

$$
\text { yaitu metode variabel terpisah }
$$
juga dijelaskan secara detail. Tugas yang diberikan adalah kerja individu di rumah mengenai soal soal praktis tentang unsurunsur persamaan diferensial dan juga tugas individu untuk mencari modelmodel sederhana yang menggunakan persamaan diferensial biasa. Dalam tugas tersebut mahasiswa juga harus dapat mengidentifikasi mana variabel bebas dan mana variabel terikat dari model yang telah mereka dapatkan. Lewat tugas ini diharapkan pengajar dapat memperoleh gambaran tentang minat awal dan keaktifan mahasiswa dalam mengikuti perkuliahan persamaan diferensial ini.

\section{See}

Dalam tahap ini dilakukan refleksi terhadap 3 tatap muka perkuliahan selanjutnya dan mengenai kesulitan dan hambatan dalam perkuliahan akan dibahas dan didiskusikan dengan dosen pengamat. Untuk tingkat keaktifan dalam siklus I ini setelah dirangkum dari tiga pertemuan ternyata masih kurang dibawah 50\%, masih sedikit mahasiswa yang bertanya ketika diminta untuk mengutarakan pendapat, tetapi untuk kemauan dalam mengerjakan tugas sudah cukup bagus terlihat dari semua tugas individu dikerjakan dan tidak terlihat indikasi adanya mahasiswa yang hanya mencontek. Untuk tugas mencari model model sederhana dapat disimpulkan bahwa $70 \%$ dari mahasiswa peserta mengerjakan dengan baik sesuai dengan perintah tugas. Sedangkan untuk pencapain prestasi di dalam siklus 1 adalah sebagai berikut :

Tabel 3. Siklus 1

\begin{tabular}{|c|c|c|c|}
\hline & $\begin{array}{l}\text { Peserta } \\
\text { Ujian }\end{array}$ & $\begin{array}{l}\text { Peserta } \\
\text { Uji } \\
\text { Remidi }\end{array}$ & $\begin{array}{l}\text { Lulus } \\
\text { KD } 1\end{array}$ \\
\hline $\begin{array}{l}\text { Banyaknya } \\
\text { Peserta }\end{array}$ & 19 & 6 & $\begin{array}{l}19 \text { dari } \\
19\end{array}$ \\
\hline Lulus & $\begin{array}{l}13(68, \\
42 \%)\end{array}$ & $\begin{array}{l}6 \quad(100 \\
\%)\end{array}$ & \\
\hline Tidak Lulus & $\begin{array}{l}6 \quad(31,58 \\
\%)\end{array}$ & 0 & \\
\hline
\end{tabular}

pada akhir siklus 1 , maka dosen model kembali mendiskusikan dengan para dosen observer untuk kemudian membahas kelemahan dan atau kekurangan yang telah terjadi. Berdasarkan analisis tersebut akan dapat diketahui komponen mana saja yang harus diperbaiki pada siklus berikutnya 
dan komponen mana saja yang telah mencapai atau bahkan melebihi target / capaian indikator. Berdasarkan hasil pencapaian prestasi mahasiswa pada akhir siklus pertama dapat disimpulkan bahwa capaian telah melewati target indikator keberhasilan pembelajaran ( 75 $\%$ ) sehingga bisa dikatakan pembelajaran cukup berhasil. Tetapi apabila dilihat masih ada mahasiswa yang harus menempuh uji remidi, maka untuk siklus selanjutnya harus dipikirkan untuk memperbaiki metode pembelajarannya. Selain itu perlu suatu cara untuk meningkatkan keaktifan mahasiswa di dalam perkuliahan dan juga meningkatkan motivasi mahasiswa dalam mengerjakan tugas yang sifatnya pengembangan materi, karena kedua hal ini dikira masih cukup kurang pada siklus pertama ini.

\section{Siklus 2 (Kompetensi Dasar 2) \\ Plan}

Dalam tahap ini dilakukan perencanaan terlebih dahulu sebelum melaksanakan 3 pertemuan dalam kompetensi dasar 2. Perencanaan meliputi metode pembelajaran yang dipakai yang sesuai dengan sifat sifat materi yang ada pada kompetensi dasar 2 . Dalam siklus ini direncanakan adanya Open Lesson Study pada pertemuan ketiga yang dihadiri oleh dosen observer. Sebelum melaksanakan Open Lesson Study diadakan terlebih dahulu diskusi dengan dosen observer untuk membahas format Open Lesson Study. Dalam Open Lesson Study ini direncanakan untuk membahas materi persamaan diferensial tingkat 2 sampai metode reduksi order, materi ini dipilih karena pemahaman tentang konsep konsep persamaan diferensial tingkat 2 menjadi dasar penting dalam langkah-langkah dalam setiap metode penyelesaian jenis jenis persamaan diferensial tingkat 2 atau lebih.

Do

Dalam tahap ini untuk pertemuan pertama dan kedua dilakukan dengan metode ceramah karena sifat materi yang didominasi oleh metode metode penyelesaian dari jenis jenis persamaan diferensial tingkat 1 dan tingkat 2. Pada pertemuan ketiga dilakukan proses Open Lesson yang dihadiri oleh dosen observer. Dosen observer masing masing diberikan lembar observasi yang telah disiapkan dalam pengamatan di dalam kelas. Materi yang digunakan sebagai penekanan dalam Open Lesson Study adalah materi persamaan diferensial tingkat 2 : pengertian, eksistensi penyelesaian, definisi dan teorema yang terkait dengan 
penyelesaian, kemudian dilanjutkan dengan membahas metode reduksi order. Metode pembelajaran pada Open Lesson ini direncanakan menggunakan gabungan antara metode ceramah dan metode diskusi, dalam diskusi ditekankan pada pemecahan masalah. Lembar observasi dibuat untuk melihat tingkat keaktifan mahasiswa di dalam proses pembelajaran dan proses diskusi kelompok. Open Lesson dimulai dengan penjelasan dan penekanan materi yang cukup sulit. Kemudian dilanjutkan dengan diskusi kelompok menyelesaikan permasalahan yang diberikan oleh dosen.

Setelah 3 kali tatap muka, pada pertemuan terakhir dilakukan ujian kompetensi dasar 2 dan didapat hasil berikut :

Tabel 4. Hasil Pencapaian Prestasi Mahasiswa pada Siklus 2

\begin{tabular}{|c|c|c|c|}
\hline & $\begin{array}{l}\text { Peserta } \\
\text { Ujian }\end{array}$ & $\begin{array}{l}\text { Peserta } \\
\text { Uji } \\
\text { Remidi }\end{array}$ & $\begin{array}{l}\text { Lulus } \\
\text { KD 1 }\end{array}$ \\
\hline $\begin{array}{l}\text { Banyaknya } \\
\text { Peserta }\end{array}$ & 19 & 4 & $\begin{array}{l}19 \\
\text { dari }\end{array}$ \\
\hline Lulus & $\begin{array}{l}15 \\
(78,95 \%)\end{array}$ & $\begin{array}{l}4 \\
(100 \%)\end{array}$ & $\begin{array}{l}19 \\
(100 \\
\%)\end{array}$ \\
\hline $\begin{array}{l}\text { Tidak } \\
\text { Lulus }\end{array}$ & $\begin{array}{l}4 \\
(21,05 \%)\end{array}$ & 0 & \\
\hline
\end{tabular}

See

Setelah melakukan proses perkuliahan dilanjutkan dengan refleksi bersama dosen observer untuk melihat apa apa yang kurang dalam pembelajaran See. Berdasarkan diskusi ini diketahui bahwa proses pembelajaran sudah berjalan baik, tetapi tingkat keaktifan masih belum begitu tinggi, hanya beberapa mahasiswa yang aktif bertanya. Untuk kerja kelompok sudah baik, walaupun ada beberapa mahasiswa yang masih belum serius dalam mengerjakan tugas kelompok. Dengan melihat hasil pada UKD 2, maka capaian prestasi mahasiswa masih tetap melebihi target dan lebih baik daripada siklus 1 . Untuk keaktifan sudah meningkat menjadi sekitar $60 \%$ dan hamper semua mahasiswa telah mengerjakan tugas baik lembar kerja individu, kelompok ataupun tugas di rumah ( sekitar $75 \%$ ). Dalam hal keaktifan harus ditingkatkan pada siklus selanjutnya dan format tugas, lembar kerja individu dan kelompok harus diperbaiki. Sedangkan untuk metode pembelajaran juga perlu adanya perbaikan.

\section{Siklus 3 (Kompetensi Dasar 3) \\ Plan \\ Dalam tahap ini direncanakan terlebih dahulu metode pembelajaran}


yang akan digunakan pada kompetensi dasar 3. Lembar kerja inidividu dan kelompok disusun dengan menitikberatkan pada latihan soal soal menyelesaikan persamaan diferensial tingkat 2 dengan metode variasi parameter dan metode koefisien tak tentu. Penekanan pada dua metode tersebut karena dari segi langkah, kedua metode tersebut langkahnya cukup panjang. Metode yang dipiilih adalah gabungan antara metode ceramah dan diskusi. Dalam siklus 3 ini juga diadakan Open Lesson Study yang kedua. Sebelum Open Lesson diadakan dulu diskusi dengan dosen observer untuk membahas proses pembelajaran yang akan dilakukan baik untuk tatap muka biasa maupun ketika Open Lesson Study.

\section{Do}

Tatap muka perkuliahan dilakukan 3 kali dengan rincian 2 tatap muka biasa dan 1 kali Open Lesson pada pertemuan ketiga. Pada pertemuan pertama dan kedua diguanakan gabungan antara metode ceramah dan metode diskusi. Kemudian pada waktu Open Lesson Study digunakan metode diskusi yang sebelumnya diawali dengan sedikit review dari materi metode variasi parameter dan metode koefisien tak tentu yang telah diajarkan sebelumnya.. Fokus dari Open Lesson Study ini adalah untuk berlatih soal soal tentang metode variasi parameter dan metode koefisien tak tentu. Pertama mahasiswa diberikan lembar kerja pribadi untuk kemudian dikerjakan terlebih dahulu secara individu, kemudian ditawarkan kepada mahasiswa apabila ada yang bersedia untuk maju ke depan kelas mempresentasikan jawabannya.

Setelah jawaban dipresentasikan oleh salah satu mahasiswa atau lebih, maka kemudian dosen model memberikan komentar dan sara tentang jawaban tersebut. Dilanjutkan dengan diskusi kelompok untuk mengerjakan soal soal yang telah disiapkan sebelumnya, kemudian hasil pada tiap kelompok dipresentasikan di depan kelas. Pada akhir Siklus 3 atau pada pertemuan ke 4 diadakan ujian kompetensi dasar 3 dengan hasil berikut

Tabel 5. Hasil Pencapaian Mahasiswa pada Siklus 3

\begin{tabular}{llll}
\hline & $\begin{array}{l}\text { Peserta } \\
\text { Ujian }\end{array}$ & $\begin{array}{l}\text { Peserta } \\
\text { Uji } \\
\text { Remidi }\end{array}$ & $\begin{array}{l}\text { Lulus } \\
\text { KD 3 }\end{array}$ \\
\hline $\begin{array}{l}\text { Banyaknya } \\
\text { Peserta }\end{array}$ & 19 & 0 & 19 \\
Lulus & 19 & 0 & $\begin{array}{l}\text { dari } \\
19 \\
(100 \%)\end{array}$ \\
$\begin{array}{l}\text { Tidak } \\
\text { Lulus }\end{array}$ & 0 & 0 & $\%)$ \\
\hline
\end{tabular}


See

Dalam tahap ini dilakukan refleksi untuk pelaksanaan Open Lesson Study. Refleksi dilaksanakan setelah perkuliahan Open Lesson Study yang diikuti oleh dosen model dan dosen observer. Dalam refleksi ini dibahas tentang pelaksanaan Open Lesson Study, saran saran yang bisa diberikan untuk perbaikan dan hal hal positif apa yang bisa dipertahankan. Berdasarkan kesimpulan dari dosen observer dan juga catatan pada lembar observasi dapat disimpulkan bahwa tingkat keaktifan dalam Open Lesson Study cukup baik sekitar $80 \%$ mahasiswa telah terlibat aktif dalam proses perkuliahan, mengerjakan tugas individu dan dalam kelompok. Kemudian berdasarkan tugas tugas pada pertemuan pertama sampai ketiga pada siklus 3 ini juga dapa disimpulkan bahwa $100 \%$ mahasiswa mengerjakan tugas dengan baik.Melihat hasil pencapaian prestasi mahasiswa pada siklus ini, $100 \%$ mahasiswa lulus ujian KD dan tidak perlu adanya remidial teaching. Hasil ini dapat dikatakan telah melebihi target capaian dan lebih baik daripada hasil yang dicapai pada siklus sebelumnya. Hal ini menunjukkan bahwa penguatan pada penjelasan detail metode dan latihan soal yang dapat memperkuat pemahaman mahasiswa terhadap metode penyelesaian suatu persamaan diferensial.

\section{Siklus 4 (Kompetensi Dasar 4)}

\section{Plan}

Dalam tahap ini direncanakan terlebih dahulu metode pembelajaran yang akan digunakan pada kompetensi dasar 4. Lembar kerja inidividu dan kelompok disusun dengan menitikberatkan pada latihan soal soal menyelesaikan sistem persamaan diferensial dengan menggunakan metode operator dan metode nilai eigen. Penekanan pada dua metode tersebut karena dari segi langkah, kedua metode tersebut langkahnya cukup panjang. Metode yang dipiilih adalah gabungan antara metode ceramah dan diskusi. Dalam siklus 3 ini juga diadakan Open Lesson Study yang kedua. Sebelum Open Lesson diadakan dulu diskusi dengan dosen observer untuk membahas proses pembelajaran yang akan dilakukan baik untuk tatap muka biasa maupun ketika Open Lesson Study. Tatap muka perkuliahan dilakukan 3 kali dengan rincian 2 tatap muka biasa dan 1 kali Open Lesson pada pertemuan ketiga. Pada pertemuan pertama dan kedua diguanakan gabungan antara metode ceramah dan metode diskusi. 
Kemudian pada waktu Open Lesson

Study digunakan metode diskusi yang sebelumnya diawali dengan sedikit review dari materi metode parameter untuk menentukan penyelesaian sistem persamaan diferensial dalam bentuk umum dan metode nilai eigen untuk menentukan penyelesaian sistem dalam bentuk normal yang telah diajarkan sebelumnya.. Fokus dari Open Lesson Study ini adalah untuk berlatih soal soal tentang metode sistem persamaan diferensial dalam bentuk umum dan metode nilai eigen untuk menentukan penyelesaian sistem dalam bentuk normal (Saparwadi,2015). Pertama mahasiswa diberikan lembar kerja pribadi untuk kemudian dikerjakan terlebih dahulu secara individu, kemudian ditawarkan kepada mahasiswa apabila ada yang bersedia untuk maju ke depan kelas mempresentasikan jawabannya. Setelah jawaban dipresentasikan oleh salah satu mahasiswa atau lebih, maka kemudian dosen model memberikan komentar dan sara tentang jawaban tersebut. Dilanjutkan dengan diskusi kelompok untuk mengerjakan soal soal yang telah disiapkan sebelumnya, kemudian hasil pada tiap kelompok dipresentasikan di depan kelas.
Tabel 6. Hasil Pencapaian Prestasi Mahasiswa pada Siklus 4

\begin{tabular}{llll}
\hline & $\begin{array}{l}\text { Peserta } \\
\text { Ujian }\end{array}$ & $\begin{array}{l}\text { Peserta Uji } \\
\text { Remidi }\end{array}$ & $\begin{array}{l}\text { Lulus } \\
\text { KD 3 }\end{array}$ \\
\hline $\begin{array}{l}\text { Banyaknya } \\
\text { Peserta }\end{array}$ & 19 & 1 & 19 dari \\
Lulus & $18(95 \%)$ & $1(100 \%)$ & $(100 \%)$ \\
Tidak Lulus & $1(5 \%)$ & 0 & \\
\hline
\end{tabular}

\section{See}

Dalam tahap ini dilakukan refleksi untuk pelaksanaan Open Lesson Study. Refleksi dilaksanakan setelah perkuliahan Open Lesson Study yang diikuti oleh dosen model dan dosen observer. Dalam refleksi ini dibahas tentang pelaksanaan Open Lesson Study, saran saran yang bisa diberikan untuk perbaikan dan hal hal positif apa yang bisa dipertahankan. Berdasarkan kesimpulan dari dosen observer dan juga catatan pada lembar observasi dapat disimpulkan bahwa tingkat keaktifan dalam Open Lesson Study cukup baik sekitar $90 \%$ mahasiswa telah terlibat aktif dalam proses perkuliahan, mengerjakan tugas individu dan dalam kelompok. Kemudian berdasarkan tugas tugas pada pertemuan pertama sampai ketiga pada siklus 3 ini juga dapa disimpulkan bahwa $100 \%$ mahasiswa mengerjakan tugas dengan baik. 
Melihat hasil pencapaian prestasi mahasiswa pada siklus ini, $95 \%$ mahasiswa lulus ujian KD dan hanya 1 mahasiswa yang harus mengikuti ujian remidial. Hasil ini dapat dikatakan telah melebihi target capaian dan walaupun sedikit menurun dari siklus sebelumnya tetapi hal ini masih bisa ditoleransi dan masih bisa dianggap berhasil mengingat tingkat kesulitan materi pada siklus ini. Kemudian kesimpulan yang sama dapat kita tarik bahwa penguatan pada penjelasan detail metode dan latihan soal yang dapat memperkuat pemahaman mahasiswa terhadap metode penyelesaian suatu persamaan diferensial.

\section{KESIMPULAN}

Berdasarkan uraian di atas dapat disimpulkan bahwa:

Perangkat pembelajaran yang disiapakan sebelum memuali Lesson Study adalah Silabus, RPP, Lembar Observasi, Lembar Kerja Individu dan Ke- lompok dan Format Tugas. Pembelajaran menggunakan Lesson Study yang memuat Open Lesson Study dapat meningkatkan keaktifan dan pemahaman mahasiswa. Bagi pengajar, Lesson Study sebagai sarana untuk bertukar pikiran, saling memberi saran dan masukan dengan dosen observer, sehingga adanya Akesulitan dan masalah dalam pembelajaran dapat didiskusikan dan dicari penyelesainnya bersama. Untuk perkuliahan persamaan diferensial, karena sifat mata kuliah yang banyak teori dan metode baru maka gabungan antara metode ceramah dan diskusi cukup membantu mahasiswa dalam memahami materi, hal tersebut dilakukan dengan memilah milah materi mana yang ditekankan lewat ceramah dan materi mana yang ditekankan lewat diskusi yang fokusnya adalah menyelesaikan soal soal.

\section{DAFTAR PUSTAKA}

Herawaty, S.,H. Chotimah, R. Joharmawan, dkk., (2010). Lesson Study Berbasis Sekolah. Bayumedia. Malang.

Lewis, Catherine C, 2002, Lesson Study : A Handbook of Teacher-Led Instructional Change, Philadelphia, PA : research for better Schools,Inc

NCTM, 2000. Pembelajaran Berstandart National Council Tesching Matematics, Erlangga, Jakarta. 
Saparwadi, Lalu.(2015). Peningkatan Kualitas Pembelajaran Kalkulus Integral Melalui Kegiatan Lesson Study di Program Studi Pendidikan Matematika. Jurnal Pendidikan Matematika.(9)1.34-49

Sujadi, I. (2011). Penerapan Blended Learning pada Perkuliahan dengan Kurikulum Berbasis Kompetensi. Prosiding Seminar Nasional Matematika dan Pendidikan Matematika UNS 2011.

Widhiartha, Ashintya Putu dkk. (2008). Lesson Study: Sebuah Upaya Peningkatan Mutu Pendidik Pendidikan Nonformal. Surabaya: Prima Printing Surabaya 